\title{
Education And Leadership Training Program In Industrial Revolution Era 4.0 To Improve Employee Creativity Ministry Of Health Of The Republic Of Indonesia
}

\author{
Haslinda Daulay, Maruf Akbar, Mansyur Ramly
}

\begin{abstract}
The Republic of Indonesia Ministry of Health (KEMENKES RI) is a government institution that serves to oversee and provide solutions to the health problems of all Indonesians. KEMENKES RI leadership training is also one of the steps taken as an internal effort of KEMENKES in the quality of human resources. The development of existing technology can be used as a supporting device in achieving the desired results. Revolution 4.0 is the basis used in decision making so that more knowledge is needed in the form of increasing competence based on information technology. The purpose of this study was to determine the effect of education and leadership training in the era of industrial revolution 4.0 on employee creativity. The research conducted at the Ministry of Health of the Republic of Indonesia uses a case study method. To be the sample, 168 employees of the Ministry of Health of the Republic of Indonesia were chosen through simple random sampling from 289 populations. This study found that there is a positive direct effect of education and leadership training in the era of industrial revolution 4.0 on employee creativity. This study concludes that employee creativity is positively influenced by education and leadership training. Therefore, to maintain employee creativity, organizations must implement leadership education and training. Finally, it was concluded that leadership education and training must be considered in producing better employee creativity.
\end{abstract}

Keywords: Employee Creativity, Education and Leadership Training

\section{INTRODUCTION}

Human resources are a very important element in an organization.(1) The failure to manage human resources can lead to disruption in achieving goals in the organization, both in performance, profit, and survival of the organization. This is because human resource management regulates the workforce in the organization (2). This human resource management can also produce good performance in an organization by means of valuation, giving remuneration in each individual member according to his or her ability to work. (3) that organizations are a group consisting of a group of people who work together to achieve a particular goal.

The Ministry of Health as a government institution has to carry out affairs in the health sector to assist the president.

\footnotetext{
Revised Manuscript Received on April 19, 2019.

Haslinda Daulay, Human Resource Management Sciences study program, Universitas Negeri Jakarta, Indonesia.

Maruf Akbar, Human Resource Management Sciences study program, Universitas Negeri Jakarta, Indonesia.

Mansyur Ramly, Human Resource Management Sciences study program, Universitas Negeri Jakarta, Indonesia.
}

Therefore, structuring the apparatus human resource management system which is an asset of the organization needs to be more prioritized. Structural position is a position that shows the duty of responsibility, authority, and rights of a state civil apparatus in order to lead a state organizational unit. Echelon III officials in carrying out their duties have duties and functions regulated in the legislation.(4)

Lately, psychologists and management have studied creativity in various domains including the domain of organizational behavior. However, it encounters a big challenge due to the complexity of the problem of creativity itself which starts from the individual skills in the dynamics of the organizational climate where employees work for a long time period for projects that are very different from the results that vary in a number of dimensions. When trying to define the construct of creativity, the first difficulty found is that this concept covers a variety of different phenomena but it is interrelated to one another, namely: creative products, creative people, creative situations, creative processes, and creative potential (5).

Based on secondary data from the post-training evaluation in 2015, it was indicated that the change project as the final result of education and training issued by the alumni was hampered by $48 \%$ meaning that the change project produced did not meet the categories according to the definition of creativity and innovation. As echelon III officials, program implementers and leading the program, it should be observant to look at change projects so that they can run according to the program's objectives, and it can be continued by the next leader if they change assignments. Creativity in determining a change project is a new idea to facilitate and launch an existing program, but not to create a new program that is difficult for the team in its work unit (6). The limitations of echelon III as a tactical officer must be truly understood because echelon III officials are not policy-making officials but officials who implement existing policies.

In today's competitive business environment, global competition forces companies to continue to look for ways to improve their services. Accordingly (7), Constantine said that creativity is a topic that has inspired researchers to explain why certain individuals, teams or organizations formulate ideas, service processes or new / useful products

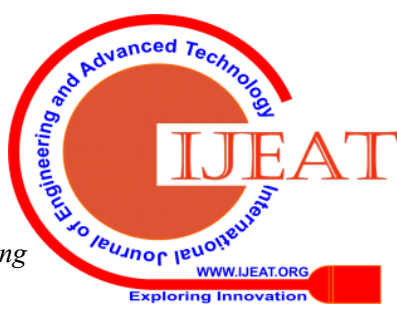


- There are five things, namely: climate organization, leadership style, organizational culture, structure \& system, and resources \& skills. Managers are responsible for coordinating, fostering, directing and controlling the creative activities of their employees towards achieving organizational goals both personally and in groups (Andriopoulos, 2010). The era of industrial revolution 4.0 was in sight. This era is marked by the use of digital technology that encouraged automation and data exchange in manufacturing technology. This era raises concerns for many parties about human work that will be replaced by the latest advanced technology

\section{LITERATURE REVIEW}

\section{A. Creativity}

It is obvious that creativity can certainly lead to human activities with their certain abilities. Human activity can produce results in accordance with predetermined expectations in which actions between rationality and human conscience. With the emerges of the third millennium in all businesses (scientific, educational, artistic, and administrative) aspects, every person begins to look into competitive advantage based on the ability of workers to be innovative and creative. This encourages all organizations to develop their management concepts and styles to prepare the climate for employees to be creative in an interactive environment that contributes to linking and transferring knowledge and obtaining accumulative experience in order to develop the best creativity for community development.

The creativity is merely about art, but it is also about valuable skills needed at all levels of the organization in all of its functions. Activities or work carried out rationally, planned and systematically can be said that the use of power or energy will be more efficient and effective in order to create creativity by producing works that can provide enjoyment and well-being of human life. With the freedom of creativity, it means the power possessed by every human being can provide maximum benefits so that there is no pressure from various parties and people will not experience obstacles.

Creativity is the process of bringing something new. it requires passion and commitment that brings to our awareness what was previously hidden and points to new life. It can be underlined that creativity is not bound by time, as long as it has commitment and enthusiasm to develop themselves, the person will become more creative.

It is understood that good ideas begin with an individual, and if they are truly creative, they will have an impact on others working in the same time. Good ideas begin with individuals, and if they are truly creative, they ultimately impact other people in the same field of work. They can change the assumptions and basic premises of a domain, and if they do, they will eventually change the material given to other individuals as they move into the field.

Creativity is much more than using your imagination to invent lots of new ideas. It is more than just using imagination to create many new ideas. Besides, creative thinking adheres to someone's lifestyle, personality traits, how to interact with other people and how to live and develop. According to Davis, creative life develops talents, suppresses unused potential and enables to result something new. Being creative also develops sensitivity to other people's problems and human problems, and leads individual to become more creative in involving imagination to solve problems.

Creativity has three main components in terms of its function: (a). expertise, including technical, procedural and intellectual knowledge; (b). creative thinking skills, determining how flexible and imaginative a person can be with problems and making effective decisions; and (c). Motivation is an internal desire to solve existing problems, and this often results in decisions that are far more creative than expected.

Another important factor of creativity allows decision makers to fully assess and understand problems which cover vision problems which cannot be seen by others. The decision-making model of a leader must be rational and improve someone's decisions therefore in decision making it also needs creativity, the ability to generate new and useful ideas. These ideas are different from what has been done before but appropriate for the problem.

Creative behavior in decision making consists of four steps: set up problem formulation (problem statement), the act of creativity begins with the problem that this behavior is designed to solve (8). Thus, problem formulation is defined as the stage of creative behavior in which we identify problems or opportunities that require unknown solutions Next step, it is Information gathering by which every problem is a solution that is rarely directly handled. Thus, we need to do something to learn more and process it. Thus, information gathering is the stage of creative behavior when the possibility of solving a problem already exists in the individual's mind.

In idea generation stage, (developing ideas) that is after gathering relevant information, individual translates knowledge into ideas. Thus, idea generation is a process of Creative behavior where developing possible solutions to problems from relevant information and knowledge. In fact, idea generation is collaborative. Finally, in the Idea evaluation stage (evaluating ideas), individual chooses from existing ideas. Thus, evaluation of ideas is a process of creative behavior in which we evaluate potential solutions to identify the best one. Sometimes the method of selection can be innovative.

Creativity behavior in organizations is the latest perspective in the development of the concept of creativity. The understanding obtained from the description of the development of this concept of creativity is a different approach to creativity but it is wrong if the approach is considered to competing each other. Organizational creativity is the creation of the value of new products, services, ideas, procedures or processes that work together in a complex social system. Individuals, groups and organizations have characteristics that are influenced by creative behavior which determines organizational creativity in a company.

From some of the meanings of creativity, stages and 
factors influence creativity as mentioned earlier, thus the writer synthesizes that creativity is a work method / action that is shown by someone to perform / present tasks and reporting according to their responsibilities more effectively and efficiently to achieve work targets. The indicators are: (1) authenticity; (2) ideas; (3) smooth production of many ideas; (4) flexibility of guiding; (5) elaboration and (6) assessment skills..

\section{B. $\quad$ Education and Leadership Training}

Level III education and leadership training is a program that will transform education and training participants towards the goals set in Level III education and training programs. Each training participant will go through a series of processes that have been prepared to bring participants to the stated goals. The purpose and set of processes contain academic and administrative elements. Academic aspects include competencies to be built, curriculum structure, and learning strategies, while the administrative aspects include the legal basis and order.

The purpose of organizing PIM III training is to develop the leadership competency of echelon III structural officials who will play a role in carrying out the duties and functions of government in their respective institutions. Thus, the target of organizing Pim III Training is the production of civil servants who have the ability to lead at echelon III structural positions. This leadership ability is manifested by his or her ability to lead changes in his or her work unit. This change can only be realized if the structural official is able to determine the area and focus of change, then influence and mobilize stakeholders to support the change.

The curriculum structure of Diklatpim III consists of six learning stages, namely: (1). Stage of Diagnosing the Need for Organizational Change; (2). Taking Ownership Stage; (3). Stage of Designing Changes and Building Teams; (4). Laboratory Leadership Stage; (5). Evaluation Phase. The five learning stages are carried out in accordance with the requirements of other training which is begun by the training needs process. In other words, Pim III Education and Training is related to planned businesses that are held to achieve mastery of the skills, knowledge and attitudes of echelon III officials (9).

Education and training are explained as follows:

Training is defined as systematic effort to modify or develop knowledge / skill / attitude through learning experience, to achieve effective performance in activity or range of activities. Its purpose, in the work situation, is to enable individuals to acquire abilities in order that they can perform adequately on tasks or jobs, and realize their potential (10).

Training is a planned and systematic effort to modify or develop knowledge / skills / attitudes through learning experience to achieve effective performance in an activity or various activities. The purpose in a work situation is to allow an individual to acquire the ability so that he or she can do the task or job adequately and realizes their potential (11).

Bernardin \& Russel defined "training is as an effort to improve employee performance". Training in this sense is any effort to improve the performance of employees on the jobs they currently hold or those related to their work (12).
This means changes in knowledge, skills, attitudes or special behavior. Training should involve learning experience and it is planned organizational activity and designed to respond to identified needs. Ideally, training is also designed to meet organizational goals and at the same time fulfill individual employee or employee goals.

Training is "A planned process to modify attitude, knowledge, or behavioral skills through learning experience to achieve effective performance in an activity or range of activity. Its purpose, in the work situation, is to develop the abilities of the individual and to satisfy the current and future needs of the organization "(13).

Basically, the training is intended to improve the mastery of various skills and techniques for implementing certain work in a relatively short time. Therefore, the training itself is an effort to develop human resources, especially in developing intellectual abilities and human personality. In a limited sense, training is to provide employees with specific and identifiable knowledge and skills for use in current work.

Based on the above description, it can be synthesized that the Level III Leadership Training is the intensity of activities carried out to improve the competence and professionalism of echelon III officials in the field of tasks embraced to achieve organizational goals, with indicators; 1) assessment of training needs (need assessment), 2) development of training programs (development), and 3) program effectiveness..

\section{Theoretical Framework}

Training means giving employees a new skill they currently need to do their jobs. In any case, training is the hallmark of good management, and this is a task manager which is always being ignored (14). In future organizational changes, of course, a manager as the challenger must understand the details of the 8-step process to lead the following organizational changes to build a sense of urgency. This sense of urgency often requires creativity. For example, the CEO might provide an (fictitious) analyst report to the executive that describes the imminent death of the company. Therefore, employees need to be trained immediately.

Furthermore, the competency details built on DiklatPim III are developing structural leadership competencies for echelon III officials who will play a role in carrying out the duties and functions of government in their respective agencies. These competencies are tactical leadership competencies, namely the ability to describe the agency's vision and mission into agency programs and lead the success of the program's implementation. This task requires a leader to have the ability to influence structural and functional officials below him, including other stakeholders to implement these programs.

Creativity in organizing activities is all forms of actions carried out consciously and rationally to organize systematically based on the level of position of a person or several people and abilities, then adjusted to the work to be done (15), and make a change that provides higher benefits 


\begin{abstract}
. Organizing activities aim to produce a form of organization in which various people are bound, done clearly, and adequate facilities and infrastructure so that the objectives to be achieved can be realized. Thus, it is suspected that there is a positive direct influence on level III leadership training on the creativity of employees of the Ministry of Health R.I. The hypothesis drawn of this study is that education and leadership training have a positive direct effect on employee creativity.
\end{abstract}

\section{METHODOLOGY/MATERIALS}

In this study, there are two variables that will be examined. The two variables consisted of educational variables and leadership training as exogenous variables and employee creativity variables as endogenous variables. In this study the approach used is a quantitative approach to analyze various phenomena of employee creativity in order to provide services at the Ministry of Health. While the type of research is survey research with a causal approach, namely research that takes samples from a population and uses a questionnaire as the most basic data collection tool. In accordance with the topic of this research, the unit of analysis in this study is echelon III structural officials who have participated in the new level III leadership training in 2014 until 2017, subordinates and superiors of the echelon III officials. Sampling using the Slovin formula, 168 people from 289 populations were selected using probability sampling techniques, namely sampling techniques that provide equal opportunities for each element of the population members to be selected as members of the sample.

\section{RESULTS AND FINDINGS}

\section{A. Data Description}

The data of this study were obtained from 168 respondents selected by using simple random sampling technique from all echelon III officials who had participated in level III leadership training in 2014 to 2016. The respondents filled out the statement of items consisting of 2 variables namely the independent variable of education and leadership training $(\mathrm{X})$ and creativity dependent variable (Y). The explanation of each variable data is as follows:

Creativity (Y)

Based on the research, the data obtained from 168 respondents that there were 31 valid statements from 33 statements, with a score range of 47 , a maximum value of 124 and a minimum value of 77 , so the mean was 101.94 , mode 96, median 102.00, standard deviation 11,644, and variance 135,577 .

Leadership education and training $(\mathrm{X})$

Based on the research, the data obtained from 168 respondents there were 28 valid statements from 31 statements, with a range of scores of 55, a maximum value of 125 and a minimum score of 70 , so that the mean was 98.80 , mode 100 , median 100.00 , standard deviation of 12,625 , and variance of 159,396 .

\section{B. $\quad$ Testing Data Analysis Requirements}

Testing requirements for data analysis include: (1) Normality Test (2) Linearity Test conducted before.

Hypothesis Test

Normality test

The first testing requirement is the Normality Test. This normality test is used to determine whether the population of the data is normally distributed or not. This test is usually used to measure ordinal, interval or ratio data. If the analysis uses parametric methods, the normality requirements must be fulfilled where the data comes from a normal distribution. In this discussion, Liliefors test was used that is by looking at the Kolmogorov-Smirnov value. The data is normally distributed if significance is greater than 0.05 .

Based on data processing using SPSS 25, the normality test output is shown in the following table 1.

Table 1. Normality Test Results

\begin{tabular}{|c|c|c|c|c|c|c|}
\hline \multicolumn{7}{|c|}{ Tests of Normality } \\
\hline & \multicolumn{3}{|c|}{ Kolmogorov-Smirnov ${ }^{\mathrm{a}}$} & \multicolumn{3}{|c|}{ Shapiro-Wilk } \\
\hline & Statistic & $d f$ & Sig. & Statistic & df & Sig. \\
\hline$Y$ (Employee creativity) &, 051 & 168 & $200^{\prime \prime}$ &, 982 & 168 &, 028 \\
\hline $\begin{array}{l}\text { X (Leadership education and } \\
\text { training) }\end{array}$ &, 059 & 168 & $200^{\circ}$ & 984 & 168 &, 048 \\
\hline
\end{tabular}

*. This is a lower bound of the true significance.

a. Lilliefors Significance Correction

\section{Linearity Test}

Linearity test aims to determine whether two variables have a relationship that is linear or not significantly. This test is usually used as a prerequisite in correlation analysis or linear regression. The SPSS 25 was used in calculating the Linearity test which is at a significant level of 0.05 . Then, two variables are said to have a linear relationship if the significance (Linearity) is less than 0.05 .

Based on data processing using SPSS 25, the linearity test output is shown in table 2 below.

Table 2 Linearity Test Results between Education and Exercise Leadership and Employee

\begin{tabular}{|c|c|c|c|c|c|c|c|}
\hline \multicolumn{8}{|c|}{ ANOVATable } \\
\hline & & & Sum ofSpylares & of & Mean Squale & F & sig. \\
\hline \multirow{5}{*}{ 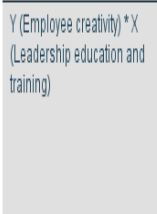 } & \multirow[t]{3}{*}{ Between Groups } & (Combined) & 12953,300 & 44 & 294,393 & 3,738 & 1000 \\
\hline & & Lineariy & 1313,465 & 1 & 1313,465 & 16,676 & 1000 \\
\hline & & Deniationfrom Lirearty & 116399,835 & 43 & 270,694 & 3,437 &, 000 \\
\hline & Withn Goulss & & 9688,105 & 123 & 787,65 & & \\
\hline & Todal & & 22661,405 & 167 & & & \\
\hline
\end{tabular}

From the above output of the linearity test results (ANOVA), it can be seen that the significance value in linearity is 0,000 . Because the significance is less than 0.05 , it can be concluded that between the variables of education and leadership training with employee creativity there is a linear relationship.

\section{Research Hypotheses Test}

After the normality test and linearity test are carried out, the results of the calculations obtained are used to test the proposed hypothesis and measure the differences in influence both directly and indirectly between variables. In 
conducting hypothesis testing based on data processing using SPSS 25, the output is obtained for testing the hypothesis as shown in table 3 below.

Table 3. Output of Hypothesis Test Results

$$
\text { Coefficients }^{a}
$$

\begin{tabular}{|c|c|c|c|c|c|c|}
\hline \multirow[b]{2}{*}{ Model } & & \multicolumn{2}{|c|}{ Unstandardized Coefficients } & \multirow{2}{*}{$\begin{array}{c}\text { Standardized } \\
\text { Coefficients } \\
\text { Beta }\end{array}$} & \multirow[b]{2}{*}{1} & \multirow[b]{2}{*}{ Sig. } \\
\hline & & $B$ & Stot. Error & & & \\
\hline \multirow[t]{2}{*}{1} & (Constant) & 79,994 & 6,919 & & 11,561 &, 000 \\
\hline & $\begin{array}{l}\text { X(Leadership education and } \\
\text { training) }\end{array}$ & .222 &, 069 &, 241 & 3,197 &, 002 \\
\hline
\end{tabular}

To prove that education and leadership learning (X) have a positive direct effect on employee creativity (Y), the hypotheses tested are as follows:

Ho: $\beta \mathrm{yx} \leq 0$

$\mathrm{H} 1 \neg: \beta \mathrm{yx}>0$

Based on the calculation of path coefficients using SPSS 25 in table 3 , the value of betax $=0.241$ with sig $=0.002$ at $\square=0.05$. Because the sig value $=0.002<0.05$, $\mathrm{H} 0$ is rejected, this means that leadership education and training $(\mathrm{X})$ has a positive direct effect on creativity (Y).

\section{CONCLUSION}

Based on the analysis that has been carried out, this study found that there are positive direct effects of education and leadership training in the industrial revolution era 4.0 on employee creativity meaning that if education and leadership training increases, it is predicted that employee creativity will increase. Besides, the performance of employees at the Ministry of Health of the Republic of Indonesia provides the following managerial implications in order to improve the creativity of employees in Indonesian Ministry of Health. Then, it it is necessary to improve leadership education and training. This means that if education and leadership training increases it will affect the increase in employee creativity. Furthermore, of the three leadership education and training indicators, there are two indicators that are already strong namely indicators of leadership development and leadership training and indicators of the effectiveness of educational programs and leadership training. For that reason, the leadership of the Ministry of Health of the Republic of Indonesia should maintain these two indicators by continuously developing leadership education and training in the era of industrial revolution 4.0 and making it more effective both in leadership training and training programs.

\section{ACKNOWLEDGMENT}

The Ministry of Health of the Republic of Indonesia

Sulfikar Sallu ID Scopus 57200989289 doctoral students of Educational Technology, Universitas Negeri Jakarta and Lecturer at the Faculty of Information Technology, Universitas Sembilanbelas November, Kolaka, Southeast Sulawesi.

\section{REFERENCES}

1. Danvila-del-Valle I, Estévez-Mendoza C, Lara FJ. Human resources training: A bibliometric analysis. Journal of Business Research. 2019.
2. Chuang C-H, Chen S-j, Chuang C-W. Human resource management practices and organizational social capital: The role of industrial characteristics. Journal of Business Research. 2013;66(5):678-87.

3. Raluca ZOLTAN RV. Organizational work groups and work teams approaches and differences. ECOFORUM. 2015;4(1):6.

4. MENTERI KESEHATAN REPUBLIK INDONESIA. KEPUTUSAN MENTERI KESEHATAN REPUBLIK INDONESIA NOMOR HK. 01.07/MENKES/17/2018. Ministerial decree. 2008:861.

5. Chung S, Lee KY, Choi J. Exploring digital creativity in the workspace: The role of enterprise mobile applications on perceived job performance and creativity. Computers in Human Behavior. 2015;42:93-109.

6. Nuscheler D, Engelen A, Zahra SA. The role of top management teams in transforming technology-based new ventures' product introductions into growth. Journal of Business Venturing. 2019;34(1):122-40.

7. Melkonyan A, Gottschalk D, V.P VK. Sustainability assessments and their implementation possibilities within the business models of companies. Sustainable Production and Consumption. 2017;12:1-15.

8. Dorst K. The Problem of Design Problems. 2000:18.

9. Lembaga Administrasi Negara. Peratutan Kepala Lembaga Administrasi Negara Tentang Pedoman Penyelenggaraan Pendidikan dan Latihan Tingkat III. 2013:60.

10. Arief Rahmana MK, Endang Soemantri, Ayi Olim. Simulation-based Training Model to Develop Project Management Competencies. Proceedings of the 2014 IEEE ICMIT. 2014:5.

11. James E.Roughton JJM. Defining Safety and Health Training Needs. A Leadership Approach. 2002:20.

12. Nassazi A. EFFECTS OF TRAINING ON EMPLOYEE PERFORMANCE Evidence from Uganda. Business Economics and Tourism 2013.

13. Masadeh M. TRAINING, EDUCATION, DEVELOPMENT AND LEARNING: WHAT IS THE DIFFERENCE? European Scientific Journal. 2003;8(10):7.

14. UNITED NATIONS ECONOMIC COMMISSION FOR EUROPE. Human Resources Management and Training. 2013:200.

15. Eze AA. Management Practice in an Organization. 2015:36.

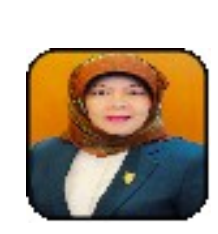

\section{AUTHORS PROFILE}

Haslinda Daulay, S1 Faculty of Economic and Business and S2 Master of Regional Development Planning, Postgraduate Doctoral Degree in Manajemen science at Universitas Negeri Jakarta. Functional Position at Minidtery of Health's HR Training Center. Email: lindadaulay96@yahoo.co id.

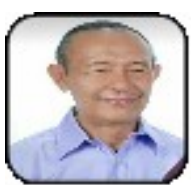

Maruf Akbar, S1\& S2 Faculty of Non Formal Education. Postgraduate Doctoral Degree in Educational Evaluation Program at Universitas Negeri Jakarta

Email : maruf.akbar@unj.ac.id

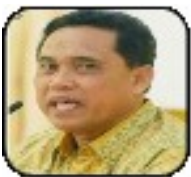

Mansyur Ramly former Rector Universitas Muslim Indonesia, Sulawesi Selatan. S1, S2 Faculty of Economics, University of Hasanuddin Makassar 